\title{
The Impact of Generation X, Y, Z and Lifestyle in Selecting Preference Retail Mediated by Brand Image Variable
}

\author{
Setiasih $^{1}$ and Triyuni Soemartono ${ }^{2}$ \\ ${ }^{1}$ STIE Bhakti Pembangunan, Jakarta, Indonesia \\ ${ }^{2}$ Universitas Prof Dr Moestopo (Beragama), Indonesia \\ setiasih.poespo@gmail.com, setiasih.poespo@gmail.com
}

\begin{abstract}
Today retail competition is inevitable. To gain market share and gain the most profit, the retailer must know the characteristics of the target market. The existence of several generations in the market, the attention of marketers. Marketers must analyze the generation of the profitable. Each generation has different characteristics, needs and desires. Satisfaction of the generation is a top priority of retailers. Retailers who are able to give trust and satisfaction to those generations will be the main choice. The purpose of this study is to look at the impact of generations $X, Y, Z$ and lifestyle in determining retail choices with brand image variables.
\end{abstract}

Keywords: Generation X, Y, Z; Lifestyle; Brand Image; Retail.

\section{Introduction}

In marketing activities, consumers are the focal point. The important thing for marketers is to have the latest knowledge of the various factors that influence consumer decisions in order to facilitate customers in the market [1] and categorize consumers into groups related to retail choices [2] as well as shopping orientation [3]. Consumers tend to display different shopping orientations, based on their individual personality and characteristics. They have a unique focus when entering a store. Some consumers consider good prices and trendy fashion, while others are attracted by brand names that provide high quality. Consumers adjust their shopping orientation to their wants and needs. Shopping orientation is a buyer style that places special emphasis on specific activities [3]. These different buyer styles have different market behaviors, including the need for different sources of information and different store preferences [3]. The shopping orientation is recognized as a complex social, cultural and economic phenomenon [4]. The orientation and behavior of consumer spending is influenced by a number of factors. Jackson, et al. in [5] argue that internal conditions such as demographics (e.g. sex and age), psychographics (lifestyle), personality, motivation, knowledge, attitudes, beliefs and feelings play an influential role in shaping consumer behavior. Blackwell, et al. in [6] also explained that psychological factors, which include motivation, perception, attitudes and individual beliefs, influence consumer purchase decisions. Personal factors, such as income levels, personality, age, occupation and lifestyle, have also been found to be important determinants of individual shopping orientation [7].

With regard to the influence of age in determining shopping orientation, Kinley, et al. in [8] note that people change the goods and services they purchase during their lifetime. For example, teenagers will be more interested in buying bright and hard colors compared to middle age or elderly individuals, who prefer a decent and refined design [6]. In addition, one young person will not be interested in buying a house, property, insurance policy or to invest in gold [9]. From all of that then age is a determinant of consumer purchases [7]. Age can be classified into several groups, this is called generation. The one generation has differences with other generations [10]. Understanding the difference of 
one generation from another can lead to the creation of an effective marketing strategy [11].

This paper discusses 3 generations of concern to marketers in order to offer products and services as well as the achievement of the established objectives of giving satisfaction to the market, gain the expected profit and control the market share to become the strongest. The lifestyle of one generation with another generation is of course different, as well as the product that becomes an option in an effort to satisfy the needs and life style, have standards, and characteristics so that the characteristics of each individual in the generation. The selection of products according to the tastes and desires of each generation will have an effect on the selection of premises or stores or retail that offer the product. Therefore, this paper analyzes the differences in generations $\mathrm{X}, \mathrm{Y}, \mathrm{Z}$ relate to lifestyle, brand image and preferred retail selection in product purchasing.

\section{Rudimentary}

\subsection{Generation $X$}

According to research, the generation X who was born in 1966 - 1976 (for the most part) consists of ambitious people with a high level of education. With education, they begin to form families with more caution and pragmatism from their parents. They also have high worries over broken home families, divorce, damaged households, children growing up without parents around and financial planning. Generation X members have attitudes and lifestyles based on factors such as age, race, and gender that are different and not all can be grouped together [12]. Generation X women love jobs that have short-term value, high ethical standards, attach importance to social equality, are responsible for improving the environment, and a balanced lifestyle [13]. Rindfleisch in [14] argues that Generation $\mathrm{X}$ tends to be more materialistic and driven by instant gratification.

In terms of marketing value, $X$ generation spends more time in the mall with money and shopping [15]. They also have high per capita expenditures and provide more for charity and churches [16] so it can be said that the $X$ generation has a bleak economic future $[14,17,18]$. Generation $X$ is highly skeptical of advertising, they still receive advertising messages and find relevant information but they are critical about honest or incorrect advertising [19]. They also tend to underestimate if they do not find something useful [15]. Boush, et al. in [20] showed skepticism of advertising at the start of Grade 6 (age 12), Brucks, et al. in [21] showing evidence of skepticism over advertising in grade 4 (age 9). Ritchie in [22] explains that generation $\mathrm{X}$ is a media connoisseur, who can choose what interests them most. Roberts \& Manolis in [15] found that Generation X generally tends to be more profitable and slower to assess advertising.

Generation $\mathrm{X}$ is a market share that has the potential as a big buyer and spends money on buying reliable products such as cars, furniture, homes, audio-visual equipment, fax machines, clothing, CDs and software [22,23], But instead become the most difficult market share for marketers [24]. Ritchie in [22] argues that the X generation does not want to be bombarded with excessive advertising. Strauss and Howe in [25] marketers need to understand some things about $\mathrm{X}$ generation are:

a. Want the impact or effect of such ads immediately,

b. Focusing on this moment, because they are not sure about the future,

c. The products offered must conform to the promise of realistic commitments,

d. $\quad$ Tired of the advertisements offered by marketers from big companies who tell them what to do [26].

Generation $\mathrm{X}$ has a willingness to buy quality products above all else therefore $\mathrm{X}$ generation seeks out the real value and benefits of advertising [27], focuses on actual product value [22] and demands to fulfill the promises of advertising and obey it [28]. 
Generation $\mathrm{X}$ is interested in the usefulness of products that meet specific needs rather than just symbols and status [22]. Miller in [29] also says that generation X has a sense of concern about their economic future, almost paranoid with fear of being cheated, and determined to use their money carefully. Generation $\mathrm{X}$ is a group of consumers who are demanding and knowledgeable about the products they buy [27]. Therefore, marketers should be able to provide useful information about their products that will be offered on the market, especially in generation X [30]. Ducoffe in [31] explains how consumers perceive the value of advertising based on the importance of information and entertainment because advertising can be deceptive and annoying, explaining the understanding of why consumers develop profitable or unfavorable attitudes about advertising [31].

\subsection{Generation $Y$}

Generation Y, born in 1977-1994 in [32] called Millennials, is a group of people who usually have certain characteristics and similar characteristics. The group is defined by certain limits, i.e. birth year or age. Generation Y consists of people born between 1977 and 2000 [33], 1980-1994 [34]. In this study the Y generation consisted of people born between 1977 and 1994. Certain characteristics and features can be found in various areas of interest, such as lifestyle, educational or occupational choices and also in shopping behavior. This specific thing led to the need to gather information about generations in general. Generation $\mathrm{Y}$ has huge purchasing power and therefore has become an important segment for marketers [35]. This generation is able to spend their money quickly $[11,36,37]$. Generation $\mathrm{Y}$ is the second largest generation group that grows influenced by brands [38] and materialistic [39]. Generation Y purchasing power has a tremendous impact on the economy and this generation is very active in the market [33]. Generation $Y$ generally does not like to read and understand monotonous information. If required to read, electronic programs are preferred [41]. Preferable communication is communication that has visual stimuli such as video and action and action action images. Generation $Y$ has a short attention; easily bored and multitask. Therefore information sources must be instant [41]. Generation $\mathrm{Y}$ is known as very sophisticated and smart in technology, immune to Traditional Marketing and sales because they not only grow, but also have seen it all and exposed it all since the early childhood. They regard modern technology as inevitable for their lives. This generation is an innovator or early adopters of innovation and more involved in online behavior, using social networks. These networks have a powerful impact on their lives as interactive online social media. The use of the internet is much wider, searching for health information, doing research work, using online banking and making reservations when visiting accommodation. Generation $\mathrm{Y}$ is a strong determinant of online buying behavior and contributes to the highest percentage of online purchases.

In retail environments, $\mathrm{Y}$ generations are paying great attention and love the changes to the products they offer such as grouping of merchandise with color or changing shop windows. Generation $\mathrm{Y}$ is a unique target market, but the $\mathrm{Y}$ genes are less loyal to the brand. Shopping is considered a recreational and entertainment activity. Browsing products in shopping centers is more important than the purchase itself [39]. Time spent in shopping centers is higher than other generations [40]. Generation Y also enjoys significantly more spending than other generations, visiting stores with a higher number of stores prior to final purchase. Time in the shopping center is spent with people like family and friends and the support of entertainment and restaurant facilities [40]. Generation Y has a very high brand awareness [33] but has a low level of loyalty [41] and it's hard to persuade this generation to be faithful. They are heavily influenced by brands that are trendy, visionary and up-to-date than uniqueness. Original and creative [42], and 
has the highest level of motivation in consuming compared to Generation $\mathrm{X}$ and Baby boomers [11].

In product purchases, the $\mathrm{Y}$ generation is influenced by brand personality, fashion knowledge and seek for brand value or convenience, and the recognition of trends in the fashion market $[33,43]$. They do this not only because of their high quality, but also because of their social status [44,45]. According to Eastman and Liu in [46]. Generation Y likes sales and discounts. Building relationships with retailers is not a major objective [47]. The product selection is done more emotionally while the selected shopping spots are more at a rational level [11].

\subsection{Generation $Z$}

Generation $\mathrm{Z}$ as a person born between 1995 and 2009 [48], is the youngest generation, where behavior and habits have not been adequately researched, also called Centennials generation, Digital generation, Generation I, Generation Internet or Text Generation. They welcome diversity, change, and accept that things must evolve. They are environmentally conscious and sensitive to social problems and differences. This generation recognizes traditional values, values family cohesion and is accountable. This generation is very pragmatic, highly individualistic, even selfish, worships hedonism, comfort, strong independence of thought and on the other is greatly influenced by the opinion of leaders who come from friends, Classmates, their friends, even from networks. With the basic characteristics that this generation was born in the era of computers, the internet, technology, e-mail and cell phones that changed the fundamental lifestyle. Generation $\mathrm{Z}$ is a global generation with diverse backgrounds, experiences and different ideas. They believe that they can influence the world, confident and optimistic

According to The Curve in [49] generation with the letter $\mathrm{Z}$ can mark the end of a generation. Generation $\mathrm{Z}$ is a sophisticated, intelligent, multi-talented, better-educated than any other generation [50], short attention span, more accuracy speed. Generation Z has self-perception that is with self-awareness formed by creating a personal profile on social networking sites. Members of this generation are sensitive to social impact. The social world is heavily influenced by products and brands that determine who is "in" and who "comes out" and who deserves to have friends or social status. Commercialization increases interest in material values and what is "cool" is the norm for popularity and is included in group. An important part of their free time is associated with online activities. In communication, face to face is replaced by online communication, this generation is also known as "silent generation." Members of this generation communicate through social networking sites, mobile contacts, spend less time with direct interpersonal communication.

Because this generation is interested in media that provides social and web networks, conducting online continuously, engaging in communication and sharing information, viewing technology as an important part of their future. The Internet is a common part of their lives and blogs are a natural communication environment. They believe the internet can be used for all types of actions. They less distinguish the virtual experience from the original because they perform various actions together, for example when working with their laptop watching TV, listening to iPod, chat, or SMS. They cannot focus on one activity for a long time. Their mentality is attached to their phone and their tendency to search for information on the internet using Google. This generation chooses the satisfaction of personal needs as a high priority, they will not work to hatch in one company, work according to career opportunities, will not even become workaholics, because enjoying life is their greatest important part [51]. They are more aware with ads that are part of marketing with knowledge-based content and more control over how marketing messages are delivered to them. Generation $\mathrm{Z}$ grows during the development of new technology and rapid technical progress, everything they need is provided by mobile 
phones and tablets. They are always online, simultaneously performing various activities, for example they chat with some people, edit video footages, or photographs, listen to music and etc. They create their own stories, blogs, photos, videos, movies, or PC games and upload them to social networks. They express themselves in the picture. The important thing for them is to not only receive media content, but they make their own. Generation $\mathrm{Z}$ pursues technological innovation in communication with curiosity and fast getting. This affects the way they socialize and communicate significantly. Readiness and speed are other words that belong to this generation. The ability to know more about other cultures makes this generation more informed, but also more tolerant of different ethnicities.

\subsection{Lifestyle}

Lifestyle refers to a unique lifestyle, interpreting life in a social context and reflecting how individuals live, and behave as consumers [52,53]. According to Huddleston, et al. in [54] lifestyle is a way of life shaped by values and experience. It is a mixture of real things like activities, interests, and opinions, which describe the interaction with the environment. Assael in [55] defines lifestyles as a mode of life that is identified by how people spend their time (activities), what they consider important in their environment (interest) and what they think about themselves and the world around them (opinion). According to Oh and Fiorito in [56] lifestyles can be influenced by consumer personalities and references, while Du Plessis in [57] explains that lifestyles refer to an individual or family way of life, describing the behavior and buying patterns especially the way that people spend their time and money.

\subsection{Brand Image}

A product brand can give a good and bad impression on the consumer [58]. When the brand image is so strongly embedded in the mind of the consumer, the product can easily gain market share [59]. Brand image is often used as an extrinsic gesture to make purchasing decisions [60]. Akaah and Korgaonkar in [61] concluded that consumers are more likely to buy well-known branded products with positive brand image as a way to lower the risk of purchasing. This argument is also supported by Rao and Monroe in [62] who say that a brand with a more positive image does have an effect of lowering the risk of consumer product perceptions and increasing positive feedback from consumers. Park, et al. in [63] suggested that brand image is a phenomenon of perception influenced by corporate communication activities. Kotler in [64] states brands are names, terms, symbols, designs used to differentiate a person's products and services from competitors. Keller in [65] defines brand image as an association or consumer perception based on their memory of a product. As such, brand image does not exist in the actual technology, features or products themselves, but is something that promotions, advertisements, or users bring. Through brand image, consumers can recognize products, evaluate quality, lower buy risk, and gain experience and satisfaction from product differentiation. Brand image can be divided into functional image, symbolic image and experience image in which the image influences consumer attitudes. The three images are as follows:

a. The functional image of product functionality can help consumers solve their consumer problems and prevent potential problems.

b. $\quad$ Symbolic image of the brand can satisfy the inner desire of consumers such as increasing self-value, social status, self-confession, and others.

c. The experiential image of a brand can satisfy consumers with diversity and stimulation so as to provide consumers' enjoyment and experience.

Consumers tend to buy products that have a good brand image [66]. This is supported by Laroche, et al. in [67] which explains that consumer confidence will be greater if choosing and using products that have a good brand image. Specifically, if product 
performance exceeds expectations, customer satisfaction increases but when expectations exceed product performance, customer satisfaction decreases. Because product performance is an important component of the brand image, the company can infer the influence of potential brand image on customer satisfaction by identifying differences in perceptions of brands between existing and non-users of the brand [24]. Brand image has a significant impact on customer satisfaction [25]. In addition, the suitability between the brand image and self-image of the customer will improve customer satisfaction and customer preferences for the brand [68]. In the literature of brand image, brand image is considered an important and significant driving force of customer loyalty to the supermarket industry $[69,70,71]$.

\subsection{Preference Retail}

Brand image embedded and stored in the minds of consumers as a result of rational and emotional evaluation will lead to brand perception, which ultimately affects the decision to buy or not to buy and how consumers value the brand depending on their perception differences [72]. Brand image reflects Ability to meet the needs and desires of consumers. The brand image also reveals the value and identity created for the customer [73]. Stores or retailers must create extrinsic, intrinsic and / or combined values for product brands where the value relies on objective features related to the experience or functional utility offered to the customer while value creation focuses on the symbolic attributes and experiences evaluated by the customer [74]. Brand image focuses not only on objective factors such as product or service quality and price, but also on subjective benefits such as psychological utilities that signify value, identity, social status, and customer differentiation by maintaining affective and mental brand perceptions [72]. Stores or retailers maintain an image by combining store image and product image with a view to maintaining and enhancing strong perceptions in the minds of consumers. Retail satisfaction or shopping satisfaction from the consumer's point of view encompasses consumer perceptions of store characteristics as well as subjective consumer evaluation of products obtained from stores [75]. The success of the store is based on the perception of quality, brand image, the range of quality products sold, the price of products, the physical facilities of the store, and the quality of service provided by salespeople [76] supported by the improvement and addition of some attributes such as atmosphere, shopping. All these attributes help maintain brand image, increase store value, build personality [77], and product names [78], gain competitiveness [75], encourage consumer loyalty [79], and bring customer satisfaction. The quality of the relationship has a strong connection with the quality of service and focuses on personal and social relationships. In clothing retailing stores, the quality of relationships between sellers and customers signifies long-term relationships with customers and thereby achieves customer satisfaction and trust building [80]. Trust, and customer satisfaction found dimensions of relationship quality in the literature (e.g. [81]).

In a study conducted by Granot, et al., in [82], the three drivers of purchasing decisions on select retail are the emotional (brand), service (retail environment) and last shopping experience. Marketers must consider these three things to attract and satisfy customers, and in particular retail brands are an emotional satisfaction and loyalty to repeat purchases [82]. The buying intention is used as an indicator of predicting consumer behavior [83]. Swinyard in [84] and Kim \& Mauborgne [85] argue that consumer spending values are the reason to visit retailers so marketers or retailers must set different actions to ensure that these values are met. Convenience, resources, product performance, service, entertainment, social interaction and atmosphere are different values as the main values consumers expect. Consumer's perceived risk becomes an important factor in understanding consumer buying behavior [86]. High levels of risk perception can cause customers not to buy. Consumers choose reputable stores to reduce the uncertainty and 
risks associated with their shopping choices [87]. The perceived risk is referred to as an individual's subjective belief over the potentially negative consequences of its purchase decision or behavior that cannot be anticipated with certainty [88]. Six major dimensions of risk in consumer decision making are financial, social, psychological, physical and time risks or comfort risks. Perceived functional and financial risk will be lower if store quality is felt high $[87,88]$. For example, social risks arise when products are seen by others and show social identity or consumer self-image [88]. Quality perception is the consumer's assessment of the superiority of the product or service offered by the company will depend on the consumer's perception of the quality that can result in repetitive purchasing behavior from loyal consumers [77].

The choice of retail is influenced by several external factors such as store-bought brands, physical location and time [77] and some intrinsic factors such as the ability to satisfy needs, preferences and put consumers in position which is better [89]. Consumers consider various factors or attributes in evaluating quality stores related to perceived quality with capacity to satisfy consumer needs. Design elements such as colors, layouts and architectures can influence the store's cognitive evaluation of stores with respect to perceived merchandise and service quality, and prices [91]. In addition to element design, social factors that add value to the same image store and merchandise with higher quality and value when purchased from a store with an upscale atmosphere [91]. The perception of a store or retail as an entity includes basic factors such as trust, reputation, and identity such as a store or retail that is categorized as top level [92]. According to the previous literature, researchers found that the perception of relationship quality had a significant impact on the intention of buying behavior [80].

\section{Data Analysis}

In this study, the sample came from Bandung, West Java of 300 respondents consisting of several levels of age that is less than 17 years, 17 years -25 years, 26 years - 35 years, 36 years - 45 years, 46 years - 55 years, and More than 55 years. The number of samples in the grouping is shown in the Table 1 below.

Table 1. Age Respondent

\begin{tabular}{|l|l|c|}
\hline & \multicolumn{1}{|c|}{ Age } & Total \\
\hline \multirow{2}{*}{ Generation X } & $>55$ & 21 respondents \\
\cline { 2 - 3 } & $46-55$ & 52 respondents \\
\hline \multirow{2}{*}{ Generation Y } & $36-45$ & 50 respondents \\
\cline { 2 - 3 } & $26-35$ & 87 respondents \\
\hline Generation Z & $17-25$ & 82 respondents \\
\cline { 2 - 3 } & $<17$ & 8 respondents \\
\hline & Total & 300 respondents \\
\hline
\end{tabular}

From the results of the questionnaire, where respondents were asked to write 3 store names where respondents used to buy daily necessities, obtained 16 names of these stores. The following table shows, the first place where the usual respondent buy with the most answers are Yogya, Borma, Alfamart, Giant, Griya, Lottemart, and Superindo. For second place, the name of the shop where the respondent used to buy daily necessities is Alfamart, Borma, Indomart, Yogya, Griya, Superindo, Carrefour, Hypermart, and Setiabudi, The third place commonly respondents come shopping is Yogya, Griya, Indomaret, Alfamart, Superindo, and Giant as described in Tables 2 and 3. 
Table 2. The Name of the Shop where the Common X Generation Respondents buy their Daily Needs for Age $>55$ years Old

\begin{tabular}{|c|c|c|c|}
\hline \multicolumn{4}{|c|}{$>55$ years old } \\
\hline The Name of Shop & $1^{\text {st }}$ choice & $2^{\text {nd }}$ choice & $3^{\text {rd }}$ choice \\
\hline \multirow{5}{*}{$\begin{array}{l}\text { Alfamart, } \\
\text { Alfamidi, Borma, } \\
\text { Borobudur, } \\
\text { Carrefour, Giant, } \\
\text { Griya, Hypermart, } \\
\text { Indomaret, } \\
\text { Judomart, } \\
\text { Lottemart, Mulia } \\
\text { Store, Setiabudi, } \\
\text { Superindo, Yogya }\end{array}$} & Yogya & Alfamart & Yogya \\
\hline & $\begin{array}{l}\text { Alfamart, } \\
\text { Borma, Giant }\end{array}$ & Borma & $\begin{array}{l}\text { Superindo, } \\
\text { Indomaret, } \\
\text { Giant, }\end{array}$ \\
\hline & \multirow{3}{*}{$\begin{array}{l}\text { Griya, } \\
\text { Lottemart, } \\
\text { Mulia Store, } \\
\text { Superindo }\end{array}$} & Indomaret & Alfamart \\
\hline & & Yogya & \multirow{2}{*}{$\begin{array}{l}\text { Alfamidi, } \\
\text { Griya, } \\
\text { Setiabudi }\end{array}$} \\
\hline & & $\begin{array}{l}\text { Borobudur, Carrefour, } \\
\text { Griya, Hypermart, } \\
\text { Judomart, Setiabudi, } \\
\text { Superindo }\end{array}$ & \\
\hline
\end{tabular}

Table 3. The Name of the Shop where the Common X Generation Respondents buy their Daily Needs for Age 46 - 55 Years Old

\begin{tabular}{|c|c|c|c|}
\hline \multicolumn{4}{|c|}{46 - 55 years old } \\
\hline $\begin{array}{c}\text { The name of the } \\
\text { shop }\end{array}$ & $1^{\text {st }}$ choice & $2^{\text {nd }}$ choice & $3^{\text {rd }}$ choice \\
\hline \multirow{6}{*}{$\begin{array}{l}\text { Alfamart, Barokah, } \\
\text { Borma, } \\
\text { Carrefour, } \\
\text { Foodhall, Giant, } \\
\text { Griya, Hero, } \\
\text { Hypermart, } \\
\text { Indomaret, } \\
\text { Lottemart, Mulia } \\
\text { Store, Traditional } \\
\text { Market, Setiabudi, } \\
\text { Superindo, } \\
\text { Shop, Yogya, } \\
\text { Yomart }\end{array}$} & Yogya & Borma & Griya \\
\hline & Borma & Yogya, Alfamart & Indomaret \\
\hline & $\begin{array}{l}\text { Carrefour, } \\
\text { Griya }\end{array}$ & Griya & Alfamart \\
\hline & $\begin{array}{l}\text { Alfamart, } \\
\text { Lottemart, } \\
\text { Setiabudi, } \\
\text { Superindo }\end{array}$ & Indomaret & Borma \\
\hline & \multirow{2}{*}{$\begin{array}{l}\text { Giant, } \\
\text { Indomaret, } \\
\text { shop, } \\
\text { Yomart }\end{array}$} & Carrefour, Giant, Yomart & $\begin{array}{l}\text { Superindo, } \\
\text { Yogya, } \\
\text { Barokah, }\end{array}$ \\
\hline & & $\begin{array}{l}\text { Barokah,Hero,Hypermart, } \\
\text { Mulia Store, Traditional } \\
\text { Market, Setiabudi, } \\
\text { Superindo, }\end{array}$ & $\begin{array}{l}\text { Foodhall, Giant, } \\
\text { Lottemart, } \\
\text { Yomart }\end{array}$ \\
\hline
\end{tabular}

Three (3) store names where the common $\mathrm{Y}$ generation respondents buy daily necessities are Yogya, Griya, Indomart, Carrefour, Superindo, Yomart, Warung, and Baru Market. Second place of choice is Indomart, Alfamaret, Borma, Giant, Yogya, and Superindo. The third place is Indomart, Alfamaret, Yogya, Lottemart, Griya, Superindo, and Shop as described in Tables 4 and 5.

Table 4. Name of Store where Y Generation Respondent used to Buy Daily Necessities for Age $\mathbf{3 6}$ - 45 years Old

\begin{tabular}{|l|l|l|l|}
\hline \multicolumn{4}{|c|}{$36-45$ years old } \\
\hline The name of the shop & \multicolumn{1}{|c|}{$1^{\text {st }}$ choice } & \multicolumn{1}{c|}{$2^{\text {nd }}$ choice } & $3^{\text {rd }}$ choice \\
\hline Alfamart, Bebeng, & Yogya & Indomaret & Indomaret \\
\cline { 2 - 4 } $\begin{array}{l}\text { Borma, Carrefour, } \\
\text { Giant, Griya, rosir, }\end{array}$ & Alfamart & Alfamart & Alfamart \\
\cline { 2 - 4 } Hypermart, & Griya & Giant & Yogya \\
\cline { 2 - 4 } & Borma, Carrefour & Borma & Giant, \\
\hline
\end{tabular}




\begin{tabular}{|c|c|c|c|}
\hline $\begin{array}{l}\text { Indomaret, } \\
\text { Kosambi, Liana, } \\
\text { Lodaya, Lottemart, }\end{array}$ & $\begin{array}{l}\text { Giant, shop, } \\
\text { Yomart }\end{array}$ & $\begin{array}{l}\text { Lottemart, SB } \\
\text { Mart, Yogya, } \\
\text { Yomart }\end{array}$ & $\begin{array}{l}\text { Lottemart, } \\
\text { Griya Borma, } \\
\text { Shop, Carrefour }\end{array}$ \\
\hline $\begin{array}{l}\text { Metro, PVJ, Baru } \\
\text { Market, Kembar } \\
\text { Market, SB Mart, } \\
\text { Sinar Jaya, } \\
\text { Superindo, Shop, } \\
\text { Coto Makasar Shop, } \\
\text { Yogya, }\end{array}$ & $\begin{array}{l}\text { Grosir, } \\
\text { Indomaret, } \\
\text { Lodaya, } \\
\text { Lottemart, } \\
\text { Baru Market, } \\
\text { Superindo }\end{array}$ & $\begin{array}{l}\text { Hypermart, } \\
\text { Kosambi, Lodaya, } \\
\text { Metro, Kembar } \\
\text { Market, Sinar Jaya, } \\
\text { Superindo, shop }\end{array}$ & $\begin{array}{l}\text { Bebeng, } \\
\text { Kosambi, } \\
\text { Liana, PVJ, } \\
\text { Superindo }\end{array}$ \\
\hline
\end{tabular}

Table 5. Name of Store where Y Generation Respondent usually to Buy Daily Necessities for Age 26 - 35 Years Old

\begin{tabular}{|c|c|c|c|}
\hline \multicolumn{4}{|c|}{ 26-35 years old } \\
\hline Name of shop & $1^{\mathrm{st}}$ choice & $2^{\text {nd }}$ choice & $3^{\text {rd }}$ choice \\
\hline \multirow{9}{*}{$\begin{array}{l}\text { Alfamart, Borma, } \\
\text { Bumi kresna, } \\
\text { Carrefour,circle k, } \\
\text { Foodhall,Giant, } \\
\text { Griya, Hero, } \\
\text { Hypermart, } \\
\text { Indomaret,Kings, } \\
\text { Lottemart,Baru } \\
\text { Market, modern } \\
\text { market, } \\
\text { batununggal, } \\
\text { Setiabudi, } \\
\text { Superindo,shop,Y } \\
\text { ogya,Yomart }\end{array}$} & Yogya & Alfamart & Alfamart \\
\hline & Griya & Indomaret & Indomaret \\
\hline & & & \\
\hline & Indomaret & Borma & $\begin{array}{l}\text { Yogya, Hypermart, } \\
\text { Borma }\end{array}$ \\
\hline & Lottemart & $\begin{array}{l}\text { Carrefour, Griya, } \\
\text { Yogya }\end{array}$ & $\begin{array}{l}\text { Carrefour, Griya, } \\
\text { Superindo }\end{array}$ \\
\hline & Borma, Carrefour & Giant & Yomart \\
\hline & Superindo & Superindo & Circle $\mathrm{k}$ \\
\hline & $\begin{array}{l}\text { Hero, Hypermart, } \\
\text { Baru Market, }\end{array}$ & $\begin{array}{l}\text { Circle k, foodhall, } \\
\text { Hero, Hypermart, }\end{array}$ & $\begin{array}{l}\text { Giant, Lottemart, } \\
\text { Setiabudi }\end{array}$ \\
\hline & $\begin{array}{l}\text { Setiabudi, shop, } \\
\text { Yomart }\end{array}$ & $\begin{array}{l}\text { modern market, } \\
\text { batununggal, } \\
\text { Yomart }\end{array}$ & $\begin{array}{l}\text { Bumi kresna, } \\
\text { foodhall, Hero, } \\
\text { Baru Market,shop }\end{array}$ \\
\hline
\end{tabular}

For the $\mathrm{Z}$ generation described in the table below that the name of the store where the most visited $Z$ respondents generation to buy daily needs is Yogya, Indomart, Alfamart, and Griya. The second most frequented place is Alfamart, Indomart, Yogya, Griya, and Giant. The third place is Indomaret, Alfamart, Superindo, and Giant as described in Tables 6 and 7.

Table 6. Name of Store where Z-generation Respondent used to Buy Daily Necessities

\begin{tabular}{|l|l|l|l|}
\hline \multicolumn{4}{|c|}{$17-25$ years old } \\
\hline \multicolumn{1}{|c|}{ Name of shop } & $1^{\text {st }}$ choice & $2^{\text {nd }}$ choice & $3^{\text {rd }}$ choice \\
\hline $\begin{array}{l}\text { Alfamart, Borma, } \\
\text { Carrefour, circle }\end{array}$ & Yogya & Indomaret & Indomaret \\
\cline { 2 - 4 } $\begin{array}{l}\text { foodhall, Giant, } \\
\text { Griya, Hero, }\end{array}$ & Indomaret & Alfamart & Alfamart \\
\cline { 2 - 4 } $\begin{array}{l}\text { Hypermart, } \\
\text { Indomaret, kircon, } \\
\text { Kosambi, Lodaya, } \\
\text { Lottemart, } \\
\text { Matahari, } \\
\text { Mulia Store, } \\
\text { Papaya,Astana }\end{array}$ & Glfamart & Borma, Yogya & $\begin{array}{l}\text { Superindo, } \\
\text { Borma }\end{array}$ \\
\cline { 2 - 4 } & Griya & Superindo & Carrefour \\
\cline { 2 - 4 } & Carrefour & Setiabudi, Giant, & Griya \\
\cline { 2 - 4 } & Cottemart & Griya & $\begin{array}{l}\text { Circle k, Giant, } \\
\text { Hypermart, } \\
\text { Setiabudi,Yomart }\end{array}$ \\
\hline
\end{tabular}




\begin{tabular}{|c|c|c|c|}
\hline \multirow{3}{*}{$\begin{array}{l}\text { anyar market, } \\
\text { Kembar Market, } \\
\text { modern batununggal } \\
\text { market, } \\
\text { SB Mart, Setiabudi, } \\
\text { Superindo, } \\
\text { shop, Yogya, }\end{array}$} & & & Lottemart \\
\hline & Borma & \multirow[b]{2}{*}{$\begin{array}{l}\text { Hypermart,kircon, } \\
\text { papaya,modern } \\
\text { batununggal } \\
\text { market, } \\
\text { shop, Yomart }\end{array}$} & \multirow{2}{*}{$\begin{array}{l}\text { Foodhall, } \\
\text { Kosambi }\end{array}$} \\
\hline & $\begin{array}{l}\text { Circle k,Setiabudi, } \\
\text { Hypermart,Hero, } \\
\text { Lodaya,astana } \\
\text { anyar market, } \\
\text { Kembar Market }\end{array}$ & & \\
\hline
\end{tabular}

Table 7. Name of Store where Z-generation Respondent used to Buy Daily Necessities

\begin{tabular}{|l|l|l|l|}
\hline \multicolumn{5}{|c|}{$<17$ years old } \\
\hline \multicolumn{1}{|c|}{ Name of the shop } & \multicolumn{1}{|c|}{$1^{\text {st }}$ choice } & \multicolumn{1}{|c|}{$2^{\text {nd }}$ choice } & $3^{\text {rd }}$ choice \\
\hline Circle k,Griya,Carrefour, & Griya & Yogya & Alfamart \\
\cline { 2 - 4 } Borma, Alfamart, Mulia & Borma & Griya & Giant \\
\cline { 2 - 4 } Store, Yogya, Indomaret, & Circle $\mathrm{k}$, & Alfamart, Mulia & Superindo \\
\cline { 3 - 4 } Giant,Superindo, Setiabudi & Carrefour & Store,Indomaret & Setiabudi \\
\hline
\end{tabular}

From the results of the questionnaire, where respondents were asked to write 3 store names where respondents used to buy clothing products (clothes, shoes, bags and accessories), obtained the name of the store. The following table shows, the first place where $\mathrm{X}$ generational respondent buy fashion products, namely Yogya, Sogo, and Metro. The second place is Metro, Sun, Borma, Yogya. The third place is Sogo, Sun, and Yogya as described in Tables 8 and 9 .

Table 8. Name of Store where Generic X Respondents Buy Ordinary Buy of Fashion Products (Clothes, Shoes, Bags and Accessories)

\begin{tabular}{|c|c|c|c|}
\hline \multicolumn{4}{|c|}{$>55$ years old } \\
\hline Name of shop & $1^{\text {st }}$ choice & $2^{\text {nd }}$ choice & $3^{\text {rd }}$ choice \\
\hline \multirow{4}{*}{$\begin{array}{l}\text { BIP, Borma, BTC, Carla, } \\
\text { Carrefour, Ciwalk, } \\
\text { Debenhams, Hush Puppies, } \\
\text { ITC, Kings, Matahari, } \\
\text { Metro, MTC, Baru Market, } \\
\text { PVJ, Sogo, Bandung Sepatu } \\
\text { Shop, Tiga Shop, Yogya }\end{array}$} & Yogya & Metro & $\begin{array}{l}\text { Carrefour, } \\
\text { Sogo, } \\
\text { Yogya }\end{array}$ \\
\hline & Sogo & $\begin{array}{l}\text { Matahari,Borma, Baru } \\
\text { Market, }\end{array}$ & \multirow{3}{*}{$\begin{array}{l}\text { BIP,BTC, } \\
\text { Ciwalk, } \\
\text { ITC, Kings, } \\
\text { Matahari, } \\
\text { Metro, MTC, } \\
\text { Baru Market }\end{array}$} \\
\hline & Borma & Carrefour, Debenhams, & \\
\hline & $\begin{array}{l}\text { BIP, Carla, Metro, } \\
\text { MTC, Tigashop }\end{array}$ & $\begin{array}{l}\text { Hush Puppies, ITC,PVJ, } \\
\text { Sogo, Bandung Sepatu } \\
\text { Shop, Yogya }\end{array}$ & \\
\hline
\end{tabular}

Table 9. Name of Store where Generic X Respondents Buy Ordinary Buy of Fashion Products (Clothes, Shoes, Bags and Accessories)

\begin{tabular}{|l|l|l|l|}
\hline \multicolumn{4}{|c|}{$46-55$ years old } \\
\hline \multicolumn{1}{|c|}{ Name/brand of shop } & $1^{\text {st }}$ choice & $\begin{array}{c}2^{\text {nd }} \\
\text { choice }\end{array}$ & $3^{\text {rd }}$ choice \\
\hline $\begin{array}{l}\text { Baltos, Balubur, BIP, Borma, } \\
\text { BTC, Carla, Carviena, }\end{array}$ & Yogya & $\begin{array}{l}\text { Borma, } \\
\text { Matahari }\end{array}$ & Sogo \\
\cline { 2 - 4 } $\begin{array}{l}\text { Carrefour, Charles n Keith, } \\
\text { Debenhams, festival city link, } \\
\text { Furla, Griya, H\&M, Hammer, }\end{array}$ & Sogo & Metro & Matahari \\
\cline { 2 - 5 } & Metro, Baru & Yogya & Baru Market \\
\hline
\end{tabular}


Istana Plaza, ITC, Kasandra, King, Mall, Mango, Matahari, Metro, mk, lv, Newlook, Baru Market, Sayati Market, PVJ, Ria Busana, Sogo, Tiga Shop, Hijab Shop, Transmart, TSM, Uniqlo, Vetohijab, Yogya, Zara, Zoya

\begin{tabular}{|l|l|l|}
\hline Market, & & \\
\hline Carla,Carviena, & Zara & BIP, Borma, Debenhams, \\
Carrefour, Charles & & Festival City Link, Furla, \\
N Keith, Griya, & & H\&M, Hammer, mall, Mango, \\
H\&M, Istana Plaza, & & Metro, MK, LV, Sayati Market, \\
ITC, Mango, Zoya & & Hijab Shop, Transmart, TSM, \\
& & Uniqlo, Yogya \\
\hline
\end{tabular}

The 3 name of stores where respondent generation $\mathrm{Y}$ used to buy fashion product (clothes, shoes, bag and accessories), obtained the name of the store. The following table shows, the first place where $\mathrm{Y}$ generation of $\mathrm{Y}$, triple, sun, and New Market respondent. The second place commonly visited by Y generation respondents is Matahari, Yogya, Metro, and BTC. The third place is the Sun, New Market, Borma, and Outlet as described in Table 10.

Table 10. Name of Store where Y Generation Respondent used to Buy Ordinary to Buy Fashion Products (Clothes, Shoes, Bags and Accessories)

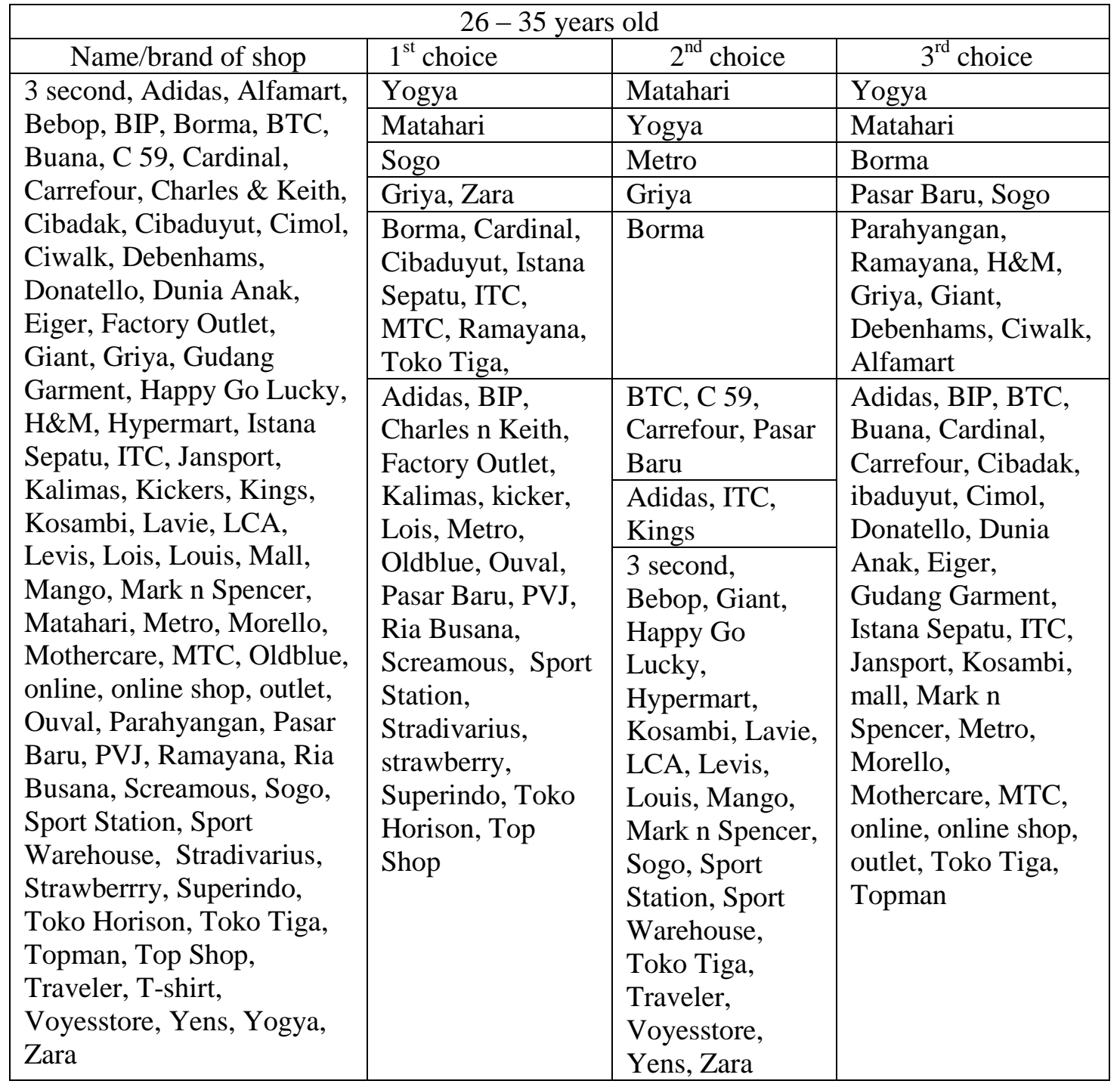

The 3 names of stores where Z-generation respondents buy ordinary clothing (clothes, shoes, bags and accessories), the name of the store is obtained. The following table 
shows, the first place where Z-generation respondent is H \& M, Yogya, Zara, and Borma. Second place is Sogo, Nike, $\mathrm{H} \& \mathrm{M}$, and Zara. The third place is Yogya, Metro, Sun, and Uniqlo as described in Tables 11 and 12.

\section{Table 11. Store Name where Z-generation Respondents Buy Ordinary Buying of Clothing (Clothing, Shoes, Bags and Accessories)}

\begin{tabular}{|c|c|c|c|}
\hline \multicolumn{4}{|c|}{$17-25$ years old } \\
\hline \multirow{4}{*}{\begin{tabular}{l}
\multicolumn{1}{c}{ Name/brand of shop } \\
ABC, Adidas, Aye, \\
Bannerrock, Bata, Bershka, \\
BIP, Boom, Borma, BTC,
\end{tabular}} & $1^{\text {st }}$ choice & $2^{\text {nd }}$ choice & $3^{\text {rd }}$ choice \\
\hline & $\mathrm{H} \& \mathrm{M}$ & \multirow[t]{3}{*}{ Sogo } & Yogya \\
\hline & \multirow[t]{2}{*}{ Yogya, Zara } & & \multirow{2}{*}{$\begin{array}{l}\text { Metro } \\
\text { H\&M, Vans, }\end{array}$} \\
\hline & & & \\
\hline $\begin{array}{l}\text { Carrefour, Charles n Keith, } \\
\text { cherry berry land, Chronic, } \\
\text { Cihapit, Converse, } \\
\text { Damnright, Distro, the }\end{array}$ & Metro, Top Man & Pasar Baru, Vans, & $\begin{array}{l}\text { Zara, Sogo, } \\
\text { Reebok, little } \\
\text { things she need, }\end{array}$ \\
\hline \multirow{2}{*}{$\begin{array}{l}\text { Executive, Factory Outlet, } \\
\text { Forever 21, Formen, Gede } \\
\text { Bage, Giant, Gildan, } \\
\text { Goodman co, Goodsdept, } \\
\text { Giordano, Griya, Gudang } \\
\text { Jam, H\&M, Heritage, } \\
\text { Homypad, Hypebeast, } \\
\text { Hypermart, Istana Sepatu, } \\
\text { ITC, Kings, little things she } \\
\text { need, Levis, Lois, Louis, } \\
\text { Mango, Mark n Spencer, }\end{array}$} & $\begin{array}{l}\text { Borma, BTC, } \\
\text { Converse, the } \\
\text { Executive, Gildan, } \\
\text { Pasar Baru, Sogo }\end{array}$ & $\begin{array}{l}\text { Borma, Matahari, } \\
\text { victoria, }\end{array}$ & $\begin{array}{l}\text { Giant, Mango, } \\
\text { Nike, Top } \\
\text { Man, Top Shop }\end{array}$ \\
\hline & \multirow{2}{*}{$\begin{array}{l}\text { Adidas, } \\
\text { Bannerrock, Boom, } \\
\text { Carrefour, cherry } \\
\text { berry land, Chronic, } \\
\text { Cihapit, Damnright, } \\
\text { Distro, Forever 21, } \\
\text { Formen, Gede } \\
\text { Bage, Giordano, } \\
\text { Griya, Hypebeast, } \\
\text { Istana Sepatu, ITC, } \\
\text { Lois, Louis, Mango, } \\
\text { Matahari, New } \\
\text { Look, Ouval, Pull } \\
\text { and Bear, PVJ, } \\
\text { Rabani, Rezka, Ria } \\
\text { Busana, Shafira, } \\
\text { Stradivarius, the } \\
\text { Excexutive, the } \\
\text { Goodsdept, Toko } \\
\text { Annisa, Toko } \\
\text { Rindy, Vans, West } \\
\text { Lee }\end{array}$} & $\begin{array}{l}\text { Yogya, Adidas, } \\
\text { Converse, Gede } \\
\text { Bage, Metro, } \\
\text { Ramayana, } \\
\text { Rumah Mode, Top } \\
\text { Man, Top Shop, } \\
\text { Uniqlo }\end{array}$ & \multirow{2}{*}{$\begin{array}{l}\text { ABC, Adidas, } \\
\text { Aye, } \\
\text { Bata, Carrefour, } \\
\text { Converse, Gede } \\
\text { Bage, Gildan, } \\
\text { Griya, Gudang } \\
\text { Jam, Heritage, } \\
\text { Hypermart, } \\
\text { Mark n } \\
\text { Spencer, } \\
\text { Matahari, } \\
\text { Nordhenbasic, } \\
\text { Online, outlet, } \\
\text { Rockstar, } \\
\text { Spyderbilt, } \\
\text { Stradivarius, } \\
\text { Toko Tiga, } \\
\text { TSM, Uniqlo, } \\
\text { Urban Coulture, } \\
\text { Visum, Widely } \\
\text { Project, Yongki, } \\
\text { Tega Lega }\end{array}$} \\
\hline $\begin{array}{l}\text { Mataharı, Metro, New Look, } \\
\text { Nike, Nordhenbasic, online, } \\
\text { outlet, Ouval, Pasar Baru, } \\
\text { PMP, Pull and Bear, Puma, } \\
\text { PVJ, Rabani, Ramayana, } \\
\text { Reebok, Rezka, Ria Busana, } \\
\text { Rockstar, Rumah Mode, } \\
\text { Shafira, Sogo, Spyderbilt, } \\
\text { Stradivarius, Tegal Lega, the } \\
\text { Excexutive, the Goodsdept, } \\
\text { the Widely Project, Toko } \\
\text { Annisa, Toko Rindy, Toko } \\
\text { Tiga, Top Man, Top Shop, } \\
\text { TSM, Uniqlo, Urban } \\
\text { Coulture, Vans, victoria, } \\
\text { Visum, West Lee, Widely } \\
\text { Project, Yogya, Yongki, Zara }\end{array}$ & & $\begin{array}{l}\text { BTC,BIP, } \\
\text { Bershka, Charles n } \\
\text { Keith, Chronic, } \\
\text { Factory Outlet, } \\
\text { Widely Project, } \\
\text { Gildan, Goodman } \\
\text { co, Goodsdept, } \\
\text { Istana Sepatu, } \\
\text { Kings, Levis, } \\
\text { Nordhenbasic, } \\
\text { PMP, Puma, the } \\
\text { Widely Project. }\end{array}$ & \\
\hline
\end{tabular}

Table 12. Name of Store where Z-generation Respondents Buy Ordinary Buying of Fashion Products (Clothes, Shoes, Bags and Accessories)

\begin{tabular}{|l|l|l|l|}
\hline \multicolumn{4}{|c|}{$<17$ years old } \\
\hline \multicolumn{1}{|c|}{ Name/brand of shop } & \multicolumn{1}{|c|}{$1^{\text {st }}$ choice } & \multicolumn{1}{|c|}{$2^{\text {nd }}$ choice } & \multicolumn{1}{|c|}{ choice } \\
\hline Carla, Giordano, Debenhams, & Yogya & Sogo, Nike, & Metro, \\
\cline { 2 - 4 } Yogya, Zara, Borma, BIP, Sogo, & Carla, Zara, & the & Matahari, \\
Nike, the Goodsdept, New Look, & Giordano, & Goodsdept, & Uniqlo, \\
Toko Elizabeth, BTC, Metro, & Borma, BIP, & New Look, & Stradivarius, \\
\hline
\end{tabular}




\begin{tabular}{|l|l|l|l|}
\hline $\begin{array}{l}\text { Matahari, Uniqlo, Stradivarius, } \\
\text { Heartwarmer }\end{array}$ & Debenhams, & $\begin{array}{l}\text { Toko } \\
\text { Elizabeth, } \\
\text { BTC }\end{array}$ & Heartwarmer \\
\hline
\end{tabular}

For questions about the name / brand of a modern store that is the most favorite place for the respondent to shop, data is obtained as seen in the Table 13 below.

Table 13. Modern Store Names / Brands that are the Most Favorite Places for Shopping Respondents

\begin{tabular}{|c|c|c|c|c|c|c|c|}
\hline \multirow[b]{3}{*}{$<17$} & \multicolumn{7}{|c|}{ Brand and Store Name } \\
\hline & $\begin{array}{l}1^{\text {st }} \\
\text { choice }\end{array}$ & $\begin{array}{c}2^{\text {nd }} \\
\text { choice }\end{array}$ & $3^{\text {rd }}$ choice & $4^{\text {th }}$ choice & $5^{\text {th }}$ choice & $\begin{array}{c}6^{\text {th }} \\
\text { choice }\end{array}$ & $7^{\text {th }}$ choice \\
\hline & $\begin{array}{l}\text { Zara, } \\
\text { Yogya }\end{array}$ & $\begin{array}{l}\text { Giorda } \\
\text { no, } \\
\text { Setiabu } \\
\text { di, } \\
\text { Borma }\end{array}$ & - & & & & \\
\hline $\begin{array}{l}17- \\
25\end{array}$ & Yogya & Sogo & $\begin{array}{l}347, \\
\text { H\&M, } \\
\text { Indomaret } \\
\text {, Vans, }\end{array}$ & $\begin{array}{l}\text { Adidas, } \\
\text { Borma, } \\
\text { Carrefour, } \\
\text { Giant, } \\
\text { Griya, } \\
\text { Matahari, } \\
\text { Ouval, } \\
\text { Pasar } \\
\text { Baru, } \\
\text { Stradivariu } \\
\text { s, TSM, } \\
\text { Uniqlo, } \\
\text { Zara }\end{array}$ & $\begin{array}{l}\text { Alfamart, BIP, } \\
\text { BTC, Charles n } \\
\text { Keith, } \\
\text { Converse, } \\
\text { Forever } 21 \text {, } \\
\text { Goodsdept, } \\
\text { Hypermart, } \\
\text { ITC, Kings, } \\
\text { Lia Collection, } \\
\text { Lottemart, } \\
\text { Metro, online, } \\
\text { papaya, Pull } \\
\text { and Bear, } \\
\text { Setiabudi,the } \\
\text { Goodsdept, } \\
\text { Topman, } \\
\text { Widely Project, }\end{array}$ & & \\
\hline $\begin{array}{l}26- \\
35\end{array}$ & Yogya & Borma & Carrefour & $\begin{array}{l}\text { Indomaret, } \\
\text { Metro }\end{array}$ & $\begin{array}{l}\text { Griya, } \\
\text { Matahari, Zara }\end{array}$ & $\begin{array}{l}\text { Ciwalk, } \\
\text { Kings, } \\
\text { Superind } \\
\text { o }\end{array}$ & $\begin{array}{l}\text { Alfamart, } \\
\text { Cardinal, } \\
\text { Happy Go } \\
\text { Lucky, Hero, } \\
\text { ITC, Levis, } \\
\text { Parahyangan } \\
\text {, Rumah } \\
\text { Mode, } \\
\text { Setiabudi, } \\
\text { Sogo, } \\
\text { Stradivarius, }\end{array}$ \\
\hline $\begin{array}{l}36- \\
45\end{array}$ & Yogya & $\begin{array}{l}\text { Mataha } \\
\text { ri }\end{array}$ & $\begin{array}{l}\text { Alfamart, } \\
\text { Borma,BT } \\
\text { C, } \\
\text { Carrefour, } \\
\text { Griya, } \\
\text { ITC, Pasar } \\
\text { Baru }\end{array}$ & $\begin{array}{l}\text { Balubur, } \\
\text { Bebeng, } \\
\text { BIP, } \\
\text { H\&M, } \\
\text { Lois, } \\
\text { Lottemart, } \\
\text { New }\end{array}$ & & & \\
\hline
\end{tabular}




\begin{tabular}{|l|l|l|l|l|l|l|l|}
\hline & & & & $\begin{array}{l}\text { Look, } \\
\text { Superindo, } \\
\text { topshop, } \\
\text { Yomart }\end{array}$ & & & \\
\hline $\begin{array}{l}46- \\
55\end{array}$ & Yogya & Borma & $\begin{array}{l}\text { Carrefour, } \\
\text { Metro, }\end{array}$ & $\begin{array}{l}\text { Griya, } \\
\text { Setiabudi, }\end{array}$ & $\begin{array}{l}\text { Lottemart, } \\
\text { Matahari, PVJ, } \\
\text { Sogo, Zara }\end{array}$ & & \\
\hline$>$ \\
55
\end{tabular}

The statement that the respondent has answered is about whether the respondent knows the following modern stores and the extent to which the respondent is familiar with the medicinal store. The results show that the order of modern stores from the first to the end or from the left to the right shows that tends to the left, the respondents are very familiar with modern stores, but the more right, the more the respondents do not know the modern store as described in Table 14 below.

Table 14. Respondents Familiar with Modern Stores

\begin{tabular}{|l|c|l|}
\hline & Age & \multicolumn{1}{|c|}{ Modern Stores } \\
\hline Generation Z & $<17$ & $\begin{array}{l}\text { Indomart, Alfamart, Yogya, Matahari, } \\
\text { Giant }\end{array}$ \\
\hline & $17-25$ & Indomart, Yogya, Alfamart, Superindo \\
\hline Generation Y & $26-35$ & Yogya, Indomart, Alfamart, Giant \\
\hline & $36-45$ & $\begin{array}{l}\text { Yogya, Indomart, Alfamart, Giant, } \\
\text { Matahari }\end{array}$ \\
\hline Generation X & $46-55$ & Indomart Alfamart, Yogya \\
\hline & $>55$ & Yogya, Indomart, Alfamart \\
\hline
\end{tabular}

\section{Conclusion}

This paper has analyzed the differences in generations $\mathrm{X}, \mathrm{Y}, \mathrm{Z}$ relate to lifestyle, brand image and preferred retail selection in product purchasing. Based on the data obtained from the questionnaires that have been filled by the respondents as generations $\mathrm{X}, \mathrm{Y}$, and $\mathrm{Z}$, it can be concluded that most respondents visited some modern stores based on brand / store name that has been known by the community, from all circles, which has been proven Quality and diversity of products and services provided, in addition to the influence of certain parties such as families who also perform other activities in addition to shopping in the modern store.

\section{References}

[1] Hollywood, L.E., Armstrong, G.A. \& Durkin, M.G., 2007, 'Using behavioral and motivational thinking in food segmentation', International Journal of Retail \& Distribution Management 35(9), 691-702.

[2] Leo, C., Bennett, R., \& Hartel, E. J. (2005). Cross-cultural differences in consumer decision making styles. Cross Cultural Management, 12, 32-61.

[3] Gehrt, K.C. \& Shim, S., 1998, 'A shopping orientation's segmentation of French consumers: Implications for catalog marketing', Journal of Interactive Marketing 12(4), 34-46.

[4] Lee, H.H. and Kim, J., 2008. The effects of shopping orientations on consumers' satisfaction with product search and purchases in a multi-channel environment. Journal of Fashion Marketing and Management: An International Journal, 12(2), 193-216.

[5] Jackson, L. Ervin, K., Gardner, P.D. \& Schmitt, N., 2001, 'Gender and the Internet: Women communicating and men searching', Sex Roles 44(5/6), 363-379. 
[6] Blackwell, R.D., Miniard, P.W. \& Engel, J.F., 2006, Consumer behavior, 10th Ed, Thomson Learning, Connecticut.

[7] Foxall, G., 2005, Understanding consumer choice, Palgrave Macmillan, Basingstoke.

[8] Kinley, T.R., Josiam, B.M. and Lockett, F., 2010. Shopping behavior and the involvement construct. Journal of Fashion Marketing and Management: An International Journal, 14(4), 562-575.

[9] Schwartz, A.J., 2004. Why a monetary history has had a long life. The Cato Journal, 23(3), 353-356.

[10] Gupta, M., Brantley, A. \& Vanessa, P.J., 2010, 'Product involvement as a predictor of Generation Y consumer decision making styles', The Business Review 14(2), 28-33.

[11] Parment, A. (2013). Generation Y vs. Baby Boomers: Shopping Behavior, Buyer Involvement and Implication for Retailing. Journal of Retailing and Consumer Services, 20 (2), 189-199.

[12] Gross David M. \& Scott, Sophfronia. (1990, July 16). "Proceeding with Caution." Time. 56-62.

[13] Burke. Ronald J. (1994). "Generation X: Measures, Sex, and Age Differences." Psychological Reports, 555-561.

[14] Rindfleisch, A. (1994). Cohort generational influences on consumer socialization. Advances in Consumer Research, 21(1), 470-476

[15] Roberts, J., Manolis, C. (2000). Baby boomers and busters: an exploratory investigation of attitudes toward marketing, advertising and consumerism. Journal of Consumer Marketing, 17(6), 481-499

[16] Herbig, P., Koehler, W., Day, K. (1993). Marketing to the baby bust generation. Journal of Consumer Marketing, 10(1), 4-9

[17] Abelman, R. (1996). Can we generalize from generation X? Not! Journal of Broadcasting \& Electronic Media, 40(3).

[18] Morton, L. (2003). Targeting Generation X. Public Relations Quarterly, 48(4), 43-45

[19] Beard, F. (2003). College student attitudes toward advertising's ethical, economic and social consequences. Journal of Business Ethics, 48(3), 217-228

[20] Boush, D., Friestad, M., and Rose, G. (1994). Adolescent skepticism toward TV advertising and knowledge of advertiser tactics. Journal of Consumer Research, 21, 165-175

[21] Brucks, M., Armstrong, G., Goldberg, M. (1988). Children's use of cognitive defenses against teLevision advertising: A cognitive response approach. Journal of Consumer Research, 14, 471-

[22] Ritchie, K. (1995, April). "Marketing to Generation X." American Demographics, 34-39.

[23] Cohen, W. \& Simons, J. (1995, May 8). "A New Spin on the Economy." U.S. News \& World Report, 54-55.

[24] Giles Jeff. (1994, June 6). "Generalizations X." Newsweek, 63-72.

[25] Strauss, W. and Howe, N., 1991. Generations: The history of America's future, 1584 to 2069. New York.

[26] Strauss, Bill \& Howe, Neil. (1993, September 26). "Hey, Boomers: Share the Wealth, Dudes." The New York Times, p. F-11.

[27] Mamey, J. (1993, September 13). "FeeUng for the Puke of the After-Boomers." Marketing, p.37.

[28] Rifkin, G. (1994, October 24). "Advertising." The New York Times, p. C-7.

[29] Miller, C. (1993, August 2). "X Marks the Lucrative Spot, but Some Advertisers Can't Hit Target." Marketing News. p. 1, 14.

[30] Serafin, Raymond \& Rickard, Leah. (1994, February 7). "Lighting Up Neon." Advertising Age. 1617.

[31] Ducoffe, Robert H. (1995, Spring). "How Consumers Assess tiie Value of Advertking."Journal of Current Issues and Research in Advertising. 17(1). 1-18.

[32] William J. Schroer (2008). Generations X, Y, Z and the Others, The Journal of the Household Goods Forwarders Association of America, Inc, Vol. XL, 9-11.

[33] Noble, M. S., Haytko, D. L., \& Phillips, J. (2009). What Drives College-age Generation Y consumers? Journal of Business Research, 62 (6), 617-628.

[34] Bednall, D., Valos, H., Adam, S.M., \& McLeod, C. (2012). Getting Generation Y to Attend: Friends, Interactivity and Half-time Entertainment. Sport Management Review, 15 (1), 80-90.

[35] Sox, C. B., Kline, S. F., \& Crews, T. B. (2014). Identifying best practices, opportunities and barriers in meeting planning for Generation Y. International Journal of Hospitality Management, 36 (1), 244-254.

[36] Pentecost, R., \& Andrews, L. (2010). Fashion Retailing and the Bottom Line: The Effects of Generational Cohorts, Gender, Fashion Fanship, Attitudes and Impulse Buying on Fashion Expenditure. Journal of Retailing and Consumer Services, 17 (1), 43-52. http://dx.doi:10.1016/j.jretconser.2009.09.003

[37] Mandhlazi, L., Dhurup, M. and Mafini, C., 2013. Generation Y consumer shopping styles: evidence from South Africa. Mediterranean Journal of Social Sciences, 4(14), p.153.

[38] Martin, C.A., \& Turley L.W. (2004). Malls and consumption motivation: an exploratoryexamination of older generation Y consumers. International Journal of Retail \& Distribution Management, 32 (10), 464-75.

[39] Bakewell, C., \& MITChell, V-W. (2006). Male versus female consumer decision making styles. Journal of Business Research. 59 (12), 1297-1900. 
[40] Gilboa, S. and Vilnai-Yavetz, I., 2010. Four generations of mall visitors in Israel: A study of mall activities, visiting patterns, and products purchased. Journal of Retailing and Consumer Services, 17(6), 501-511.

[41] Jain, V., \& Pant, S. (2012). Navigating Generation Y for Effective Mobile Marketing in India: A Conceptual Framework. International Journal of Mobile Marketing, 7 (3), 56-65.

[42] Miller, K., \& Mills, M. (2012). Fashion Marketing and Consumption of Luxury Brands. Journal of Business Research, 65 (10), 1471-1479.

[43] Bergh van den, J., \& Behrer, M. (2011). How Cool Brands Stay Hot. Branding to Generation Y. London: Kogan Page.

[44] Phau, I., \& Cheong, E. (2009). How Young Adult Consumers Evaluate Diffusion Brands: Effects of Brand Loyalty and Status Consumption. Journal of International Consumer Marketing, 21 (2), 109 123.

[45] O'Cass, A., \& Siahtiri, V. (2013). In search of status through brands from Western and Asian origins: Examining the changing face of fashion clothing consumption in Chinese young adults. Journal of Retailing and Consumer Services, 20 (6), 505-515.

[46] Eastman, J.K., \& Liu, J. (2012). The impact of generational cohorts on status consumption: an exploratory look at generational cohort and demographics on status consumption. Journal of Consumer Marketing, 29 (2), 93-102.

[47] Ballard, B. et al. (2013). Relationship Marketing and the Net Generation of Couponers. In Global Conference on Business and Finance Proceedings (403-407). San Jose (Costa Rica): The Institute for Business and Finance Research.

[48] Williams, S. (2010). Welcome to generation Z. B\&T Magazine, 60(2731), 12-12.

[49] The Curve. (2013, March). The Z Factor: And Introducing the Centennials. Retrieved from http://thecurvereport.com/category/trends/the-Z-factor/

[50] Matthews, V. (2008). Generation Z. Personnel Today, 9/16, 48-51.

[51] CA-Wikia-GenZ-Survey (2013). GenerationZ: A Look at the Technology and Media Habits of Today's Teens. PR Newswire. PR Newswire US. 03/19/2013.

[52] Loudon, D. L. and Dilla-Bitta, A. J. (1993). Consumer Behavior: Concepts and Applications, 4th Ed. New York: McGraw-Hill

[53] Hawkins, D. I., Best, R. J. and Coney, K. A. (2001). Consumer Behavior: Building Marketing Strategy, 8th ed. Burr Ridge, IL: Irwin Inc.

[54] Huddleston, P. T., Ford, I. M. and Mahoney, M. A. (1990). The relationship between importance of retail store attributes and lifestyle of mature female consumers. Journal of Consumer Studies and Home Economics 14 (1): 71-85.

[55] Assael, H. (1998). Consumer Behavior and Marketing Action 6Th edition. New York: International Thomson Publishing.

[56] Oh, J. \& Fiorito, S.S., 2002, ‘Korean women's clothing brand loyalty', Journal of Fashion Marketing and Management 6(3), 206-222. http://dx.doi. org/10.1108/13612020210441328

[57] Du Plessis, M., 2007. The role of knowledge management in innovation. Journal of knowledge management, 11(4), 20-29.

[58] Grewal, D., Krishnan, R. R., Baker, J., \& Borin, N. (1998). The effects of store name, brand name and price discounts on consumers' evaluations and Purchase intentions. Journal of Retailing, 74(3), 331352.

[59] Shamma, H. M., \& Hassan, S. S. (2011). Integrating product and corporate brand equity into total brand equity measurement. International Journal of Marketing Studies, 3(1), 11-20.

[60] Richardson, P., Dick, A., Jain, A.K., 1994. Extrinsic and intrinsic cue effects on perceptions of store brand quality. Journal of Marketing 58 (4), 28-36.

[61] Akaah, I. P. and Korgaonkar, P. K. (1988). A Conjoint Investigation of the Relative Importance of Risk Relievers in Direct Marketing, Journal of Advertising Research 28 (4), 38-44.

[62] Rao, Akshay R. and Monroe, Kent B. (1988). The Moderating Effect of Prior Knowledge on Cue Utilization in Product Evaluations, Journal of Consumer Research 15 (2), 253-264.

[63] Park, C.W., Jaworski, B.J. and Maclnnis, D.J. (1986) Strategic Brand Concept-Image Management. Journal of Marketing, 50, 135-145.

[64] Kotler, Philip (2000) Marketing Management: Analysis, Planning, Implementation, and Control, 10th ed., New Jersey: Prentice-Hall.

[65] Keller, K. L. (1993), "Conceptualizing, Measuring, and Managing Customer-Based Brand Equity“, Journal of Marketing Research, 29: 1-22.

[66] Kamins, M. A., \& Marks, L. J. (1991). The perception of kosher as a third party certification claim in advertisingfor familiar and unfamiliar brands. Journal of the Academy of Marketing Science, 19(3), 177-185.

[67] Laroche, M., Kim, C., \& Zhou, L. (1996). Brand familiarity and confidence as determinants of purchase intention: An empirical test in a multiple brand context. Journal of Business Research, 37(2), $115-120$. 
[68] Wu, P. C., \& Wang, Y.-C. (2011). The influences of electronic word-of-mouth message appeal and message source credibility on brand attitude. Asia Pacific Journal of Marketing and Logistics, 23(4), 448-

[69] Dodds, W. B., Monroe, K. B., \& Grewal, D. (1991). Effects of price, brand, and store information on buyers' product evaluations. Journal of Marketing Research, 307-319.

[70] Wang F., Zhang, H., Zang, H., \& Ouyang, M. (2005). Purchasing pirated software: an initial examination of Chinese consumers. Journal of Consumer Marketing, 22(6), 340-351.

[71] Garretson, J. A., \& Clow, K. E. (1999). The influence of coupon face value on service quality expectations, risk perceptions and purchase intentions in the dental industry. Journal of Services Marketing, 13(1), 59-72.

[72] Erdil, T. S., Uzun, Y., (2010), Marka Olmak, Beta Publishing, 2nd ed., Istanbul.

[73] Rayburn, S.W., Voss, K.E. (2013).”A model of consumer's retail atmosphere perceptions”, Journal of Retailing and Consumer Services, 20: 400-407.

[74] Högström,C., Gustafsson, A., Tronvol, B. (2015). "Strategic brand management: Archetypes for managing brands", Journal of Business Research, 68: 391-404.

[75] Torres, I.M., Summers, T. A., Belleau, B.D. (2001). "Men's shopping satisfaction and store preferences", Journal of Retailing and Consumer Services, 8: 205-212.

[76] Beristain, J.J., Zorrilla, P. (2011). "The relationship between store image and store brand equity: A conceptual framework and evidence from hypermarkets", Journal of Retailing and Consumer Services, 18: $562-574$.

[77] Das, G. (2014). "Linkages of retail personality, perceived quality, and purchase intention with retailer loyalty: A study of Indian non-food retailing", Journal of Retailing and Consumer Services, 407-414.

[78] Bao Y., Bao Y., Sheng S., (2011), "Motivating purchase of private label brands: effects of store image, product signatureness and quality variation", Journal of Business Research, Vol.64, Issue 2, 220-226.

[79] Labeaga, J.M., N. Lado, M. Martos. (2007)."Behavioral loyalty towards store brands", Journal of Retailing and Consumer Services, 14: 347-356.

[80] Tripathi, G., Dave, K. (2013) "Store format choice and relationship quality in apparel retail: A study of young and early-middle aged shoppers in New Delhi region", Journal of Retailing and Consumer Services, 20: 479-487.

[81] De Canniére, M.H., De Pelsmacker, P., Geuens, M. (2010). "Relationship quality and purchase intention and behavior: The moderating impact of relationship strength", Journal of Business and Psychology, 25(1): 87-98.

[82] Granot, E., Greene, H., Brashear, T.G. (2010). "Female consumers decision-making in brand-driven retail", Journal of Business Research, 63:801-808.

[83] Wu, P.C.S., Yeh, G.Y-Y., Hsiao, C-R. (2011). "The effect of store image and service quality on brand image and purchase intention for private label brands", Australasian Marketing Journal, 19: 30-39.

[84] Swinyard R. W., (1998), Shopping mall customer values; the national mall shopper and the list of values, Journal of Retailing and Consumer Services, Vol. 5, No. 3, 167-172.

[85] Kim, C., and Mauborgne, R. (2000). "Knowing a business idea when you see one", Harvard Business Review, Sept-Oct., 129-138.

[86] Stone, R. N., Gronhaug, K. (1993). "Perceived risk: Further considerations for the marketing discipline", European Journal of Marketing, 27(3): 39-50.

[87] Aghekyan-Simonian, M., Forsythe, S., Kwon, W.S., Chattaraman, V. (2012). "The role of product brand image and online store image on perceived risks and online purchase intentions for apparel", Journal of Retailing and Consumer Services, 19: 325-331.

[88] Diallo, M.F. (2012). "Effects of store brand price-image on store brand purchase intention: Application to an emerging market", Journal of Retailing and Consumer Services, 19: 360-367.

[89] Liljander, V., Polsa, P., Riel, A. (2009). "Modelling consumer responses to an apparel store brand: store image as a risk reducer", Journal of Retailing and Consumer Services, 16: 281-290.

[90] Luo, M.M., Chen, J-S., Chin, R.K.H., Liu, C-C. (2011). "An examination of the effects of virtual experiential marketing on online customer intentions and loyalty", Serv. Ind. Journal, 31(13): 21632191.

[91] Kumar, A., Kim, Y-K. (2014). "The store- as- a- brand strategy: The effect of store environment on customer responses", Journal of Retailing and Consumer Services, 21: 685-695.

[92] Elsbach, K.D. (2003). “Organizational perception management”, Research in Organizational Behavior, 25: $297-332$ 
International Journal of $u-$ and e- Service, Science and Technology Vol.10, No.8 (2017) 